\title{
Religion, mission and national development: A contextual interpretation of Jeremiah 29:4-7 in the light of the activities of the Basel Mission Society in Ghana (1828-1918) and its missiological implications
}

\begin{tabular}{|c|c|}
\hline $\begin{array}{l}\text { Author: } \\
\text { Peter White }{ }^{1}\end{array}$ & \\
\hline $\begin{array}{l}\text { Affiliation: } \\
{ }^{1} \text { Department } \\
\text { Religion and } \mathrm{N} \\
\text { University of } \mathrm{P} \\
\text { South Africa }\end{array}$ & $\begin{array}{l}\text { Science of } \\
\text { Missiology, } \\
\text { retoria, }\end{array}$ \\
\hline $\begin{array}{l}\text { Corresponden } \\
\text { Peter White }\end{array}$ & ce to: \\
\hline $\begin{array}{l}\text { Email: } \\
\text { pastor_white }\end{array}$ & @hotmail.com \\
\hline $\begin{array}{l}\text { Postal address } \\
\text { Private Bag X2 } \\
0028 \text {, South A }\end{array}$ & $\begin{array}{l}\text { :0, Hatfield } \\
\text { frica }\end{array}$ \\
\hline $\begin{array}{l}\text { Dates: } \\
\text { Received: } 04 \mathrm{~F} \\
\text { Accepted: } 04 \\
\text { Published: } 09\end{array}$ & $\begin{array}{l}\text { eb. } 2015 \\
\text { May } 2015 \\
\text { July } 2015\end{array}$ \\
\hline $\begin{array}{l}\text { How to cite th } \\
\text { White, P., } 201 \\
\text { mission and } n \\
\text { development: } \\
\text { interpretation } \\
29: 4-7 \text { in the I } \\
\text { activities of th } \\
\text { Mission Societ } \\
\text { (1828-1918) a } \\
\text { missiological ir } \\
\text { Verbum et Ecc } \\
\text { Art. \#1419, } 6 \\
\text { http://dx.doi.c } \\
\text { ve.v36i1.1419 }\end{array}$ & $\begin{array}{l}\text { is article: } \\
\text { 5, 'Religion, } \\
\text { ational } \\
\text { A contextual } \\
\text { of Jeremiah } \\
\text { light of the } \\
\text { e Basel } \\
\text { ty in Ghana } \\
\text { and its } \\
\text { mplications', } \\
\text { lesia } 36(1) \text {, } \\
\text { oages. } \\
\text { rg/10.4102/ }\end{array}$ \\
\hline $\begin{array}{l}\text { Note: } \\
\text { Dr Peter Whit } \\
\text { postdoctoral r } \\
\text { of Prof. Nelus } \\
\text { Head of Depar } \\
\text { Science of Reli } \\
\text { Missiology of } \\
\text { of Theology, U } \\
\text { Pretoria, Preto } \\
\text { South Africa. }\end{array}$ & $\begin{array}{l}\text { is a } \\
\text { esearch fellow } \\
\text { Niemandt, } \\
\text { rtment of } \\
\text { igion and } \\
\text { the Faculty } \\
\text { Iniversity of } \\
\text { ria, }\end{array}$ \\
\hline Read online: & \\
\hline 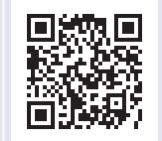 & $\begin{array}{l}\text { Scan this QR } \\
\text { code with your } \\
\text { smart phone or } \\
\text { mobile device } \\
\text { to read online. }\end{array}$ \\
\hline
\end{tabular}

We cannot realistically analyse national development without factoring religion into the analysis. In the same way, we cannot design any economic development plan without acknowledging the influence of religion on its implementation. The fact is that, many economic development policies require a change from old values, attitudes, beliefs and behaviour patterns of the citizenry to those that are supportive of the new policy. Christianity has become a potent social force in every facet of Ghanaian life, from family life, economic activities, occupation, and health to education. In the light of the essential role of religion in national development, this article discusses the role the Basel Mission Society played in the development of Ghana and its missiological implications. This article argues that the Basel Mission Society did not only present the gospel to the people of Ghana, they also practicalised the gospel by developing their converts spiritually, economically, and educationally. Through these acts of love by the Basel Mission Society, the spreading of the Gospel gathered momentum and advanced.

Intradisciplinary and/or interdisciplinary implications: The article contributes to the interdisciplinary discourse on religion and development with specific reference to the role of the Basel Mission Society's activities in Ghana (1828-1918). It provides missiological implications of their activities in the light of the broader Ecumenical discourses.

\section{Introduction}

Jeremiah 29:4-7 gives us an idea of how God is concerned about national development and the role believers should play in getting this job done no matter how limited we are. Although the purpose of this article is not to do an exegetical study of the text, it argues that the prophetic message in Jeremiah 29:4-7 has a developmental undertone from a religious perspective. Jeremiah wrote:

Thus says the LORD of hosts, the God of Israel, to all the exiles whom I have sent into exile from Jerusalem to Babylon, 'Build houses and live in them; and plant gardens, and eat their produce.' Take wives and become the fathers of sons and daughters, and take wives for your sons and give your daughters to husbands, that they may bear sons and daughters; and multiply there and do not decrease. 'And seek the welfare of the city where I have sent you into exile, and pray to the LORD on its behalf; for in its welfare you will have welfare. (Jr 29:4-7; New American Standard Bible [NASB])

Though this message was sent to the Jews who were in exile in Babylon, its content is still relevant to Christians and all missionary organisations. Mission is recognised as having its beginning in the initiative or mission of God 'missio Dei' (eds. Balia \& Kim 2010:4). In this view, the text tells us how important it is for religious people to participate in national development in order to transform society. It also informs us why Daniel and his three friends, Mordecai, Esther, and Nehemiah later held key government positions and were able to act on behalf of their people in their host country. This understanding gives us a base from which we can argue that we cannot realistically analyse national development without factoring religion into the analysis (Cordaid, ICCO \& the Institute of Social Studies, 2006; Naude 1991:83-85). In the same way, we cannot design any economic development plan for Ghana without acknowledging the influence of religion on its implementation. In fact, economic development policy requires a change from old values, attitudes, beliefs and behaviour patterns of the citizenry to those that are supportive of the new policy. That change is unlikely to occur where the designers of the plan failed to take into account the sources of motivation for implementing of the plan. Religion, particularly Christianity, has become 
a potent social force in every facet of Ghanaian life, from family life, economic activities, occupation, and health to education (Ghana Statistical Service 2012:1, 6, 40).

According to Weber (2002:24, 30-33, 37), religious practices and beliefs have important consequences for the economic development of a community or nation. Weber links the rise of industrial capitalism to the Protestant work ethic that instilled in its adherents the values of thrift, trust, integrity, honesty, hard-work, and fairness. Religion is a unified system of beliefs and practices relative to sacred things, that is to say, things set apart and forbidden. The concept of the 'sacred' is relevant to the welfare of the community (Buijs 2004:105). In fact, the relationship between religion and development is likely to be complementary as long as religious beliefs and practices promote 'moderation' rather than 'extremes' (Grier 1997:47-50; Marshall 1999:3-4).

According to Wilson (1989:145-158), national development is a large-scale investment project to develop the infrastructure of a country. It requires central planning and monitoring on a national level and implementation on a micro, local level. It also requires adequate funding from government agencies, religious organisations, nongovernmental organisations, and citizens. Holistic national development focuses on a progressive realisation of the fullest possible and balanced flourishing of human and natural resources (Iroegbe 1996:148) as well as the physical, psychological, emotional and spiritual needs of every person in the community, not only the present generation but also future generations (Adei 2004:7-12; Odumuyiwa 2006:211). National development can therefore be described as the overall development or a collective socioeconomic, political as well as religious advancement of a country or nation.

Pierson (1989:7) argues that, the missional assignment of the church is transforming society through the good news, followed by the act of love. That is, the church participate in the mission of God (missio Dei) to transform society (World Council of Churches 2013a:53, 60; eds. Balia \& Kim 2010:4, 31; Bosch 1991:389-392).

In this regard, this article seeks to explore the role the Basel Mission Society played in the development of Ghana (Gold Coast) and its missiological implications. Though researches have been done on the activities of the Basel Mission Society in Ghana, there is no research on the developmental perspective of their activities and the missiological implications of those activities. This is the gap this article seeks to close.

Though development is a broad subject, the research was limited to social, economic, spiritual, and educational development. In view of the objective of this research, descriptive historical analysis and literature study were therefore employed for the study. It should also be noted that, before Ghana's independence on March 06, 1957, it was called the Gold Coast. Therefore, the name Gold Coast in this article refers to Ghana.

\section{Basel Evangelical Mission Society}

The presence of the Basel Evangelical Mission Society in the Gold Coast (Ghana), from 1828 to 1918, was as a result of the request made for missionaries by a Danish Governor Major Richelieu (Omenyo 2006:53). When Major Richelieu first arrived at the Gold Coast around 1824 he found that the chaplain's post at the castle had been vacant for 15 years. He also observed that the religious and moral life of the colony was at very low ebb. To rectify this situation, he revived public worship, which he conducted himself. He established a school in which he also taught, and his enthusiasm and concern for a good Christian life compelled him to baptise about 150 of the pupils in the school. These initial activities encouraged the indigenes to appeal to him to bring them a minister when he was going to Denmark on leave in 1826.

Richelieu sent the request to Mr. Ronne, a representative of the Basel Mission in Denmark. Ronne forwarded the request to the King of Denmark through the Crown Prince for approval. The King warmly granted the Basel Mission Society approval to open an agency on the Gold Coast. Under these circumstances, the Basel Mission agreed to initiate a mission on the Gold Coast under the protection of the Danes. Through various negotiations, four pioneer missionaries (K.F. Salbach, G. Helzworth, J.G. Schmidt and J.P. Henke) were sent to the Gold Coast. They arrived in Christiansburg in December 1828. Two of them concentrated their efforts in Christiansburg, whilst the other two moved along the coast towards the east (Agbeti 1986:63).

Unfortunately, in August 1829, Helzworth, Salbach and Schimdt died and on 22nd November 1831, Henke also died. Though their deaths seemed to make the mission a disappointing venture, the Basel Committee once again sent three missionaries - Revs. P.P. Jager, Andreas Riis and C.F. Heinze. They arrived in Christiansburg in March 1833. Within four months Heinze and Jager were dead. Riis became ill, but he was saved by an African traditional health practitioner (herbalist). For years Riis was compelled by the Danish chaplain to restrict his activities on the coast to only help improve the moral life of the indigenes (Smith 1966:54).

In 1836, Riis and a Danish merchant George Lutterodt entered Akropong in Akwapim and established a new station there. Riis enjoyed better health in this area because it was a hilly area. The relocation to Akropong provided a turning point in the life of the Basel Mission because this move meant that their sphere of work was taken to the rural people, who offered more hope. Strategically, Akropong was also on the way to Kumasi, the capital of the great Ashanti Kingdom. It therefore became a strategic mission station to reach the western and northern belt of Ghana and beyond (Reindorf 2007:220). In 1837 two missionaries, I. Murdter and A. Stanger, with Miss Ana Walters (the fiancée of Riis) in their company, came to the Gold Coast. Stanger died within a year and Murdter followed in 1838. 
Before Murdter's death, he and Riis travelled to the Volta Region, and in 1839 Riis alone travelled westwards reaching Kumasi. In 1840, he returned home.

At Akropong, Riis was a friend to Nana Addo Dankwah I, the Akropong chief. He could not convert him because the King told him the Bible was for whites and the gods were for Africans; no African man would marry only one woman. When Riis was going home, the King told him that if African men were to see any African man married to only one woman, they would accept the white man's religion. The Basel Committee wanted to abandon the work in the Gold Coast because of the heavy loss of lives, but Riis was of the opinion that things would work out eventually and therefore proved adamant. Nana Addo Dankwah's request was made known to the Basel Mission. As a result the Committee resolved to transplant into the Gold Coast people of African descent 'Negroes' from a Danish territory where some had become Christians (Odamten 1978:135).

Riis sailed with two other colleagues from London in May 1842 to Jamaica in the West Indies, where 24 immigrants comprising of six families - were recruited for the Gold Coast. On the arrival of the West Indians at the Gold Coast on 17 April 1843, they were all attached to the Akropong station. Two years later two of the immigrant families were transferred to Aburi. This second missionary effort was accompanied by a policy of evangelising the children who would later grow into Christian adults. By 1848 ( 5 years after the arrival of the West Indians) there were 40 adult converts, as well as three hundred children receiving regular Bible and academic training (Omenyo 2006:53).

The Basel Mission showed progress or expansion from 1851 to 1914 in the Ga, Akwapim and Krobo districts. The Osu station was established in 1845 but it was difficult to evangelise in the area because their belief in the indigenous religion and customs was so strong that the inhabitants did not pay much heed to Christian preaching. When Zimmerman moved the station from Christiansburg to Abokobi in 1854, things began to improve and this enabled him to build a small Christian Community at Abokobi in order to separate the new converts from their communities and to help them grow in Christ. In 1855 Zimmerman and Locher entered the Krobo district, and in 1859 a permanent station was established at Odumase. In 1857, a local fetish priest, Paul Mohenu was converted at the age of 60 . The creation of the Odumasi mission station opened the door for Zimmerman to have a friendly relationship with Chief Odonkor Azu of Odumase, who eventually offered his twelve year old son, Tei, to Zimmerman to be trained as a Christian (Presbyterian Church of Ghana 2013b).

From Akropong, Simon Suss opened a station at Gyadam in the Akim area in 1853, and in 1857 the first converts were baptised. Tribal wars between Akim Abuakwa and Akim Kotoku led to the destruction of the Gyadam station. A new station was therefore opened at Kibi by David
Eisenschmidt. Though the chief of Kibi, Nana Amoako Atta I, was very hostile towards them, they still managed to establish a school there.

Zimmerman opened stations at Anum and in Akuse in 1864, with the Akuse station also being used as a mission trading post. The mission station at Anum was destroyed in 1869 by the Ashantis, and the missionaries, Reverend and Mrs. Ramseyer and Kühne were taken prisoner to Kumasi. From 1870 to 1914 the mission succeeded in extending its mission work from the Akwapim ridge to Kwahu, Akim and Ashanti and across the Volta as far as Yendi in the north in 1913. Bompata in Ashanti was developed into an industrious Christian village. Nsaba station became the largest station after Akropong.

The most frustrating of all the problems the missionaries encountered was World War I (1914-1918). Based on the advice of the British governor of the Gold Coast at the time, Sir Hugh Clifford, all the German missionaries were repatriated. The request for repatriation by the thengovernor was a bitter pill for the Basel Mission to swallow after about 90 years of devoted service in this mission field. In an attempt to fill this void, the Scottish Missionary Society working at Calabar in Nigeria was requested to send a missionary to take charge of the Presbyterian work on the Gold Coast (Hildebrandt 1987:200; Presbyterian Church of Ghana 2013a).

\section{Developmental policies and strategies of the Basel Mission Society}

The coming of the Basel Mission Society to Ghana was not only to evangelise but also to help develop believers in the areas of education, trade and infrastructure development (Smith 1966:52-55):

Christ wants his church not to be meaningless in society or to be pushed to the periphery ... [but] ... to be right at the centre of things, right where the action is. (Hendriks 2010:275; Sarpong 1990:9)

Kudadjie and Aboagye-Mensah (1991:33) state: that the church has a valid case to be involved in the affairs of the state in all aspects including national politics.

This implies that the mission of the church is not only to preach the gospel but also to be concerned about the welfare of the people within and outside the church. The church is called to service (diakonia), in every geopolitical and socioeconomic context; living out the faith and hope of the community of God's people, and witnessing to what God has done in Jesus Christ (eds. Walls \& Ross 2008:35, 46-47). Through service the church participates in God's mission. The church is called to be a diaconal community manifesting the power of service over the power of domination; enabling and nurturing possibilities for life; and witnessing to God's transforming grace through acts of service that hold forth 
the promise of God's reign (World Council of Churches 2013b:68). The following were some of the major mission policies and strategies of the Basel Mission in the Gold Coast.

\section{Salem concept}

Good relationships are essential in any development programme. They are the bridge across which ideas and values are carried (Hiebert 1989:75). In order to build a good relationship with the indigenous Christian converts, the Basel Missionaries established Christian communities known as 'Salem' (Agbeti 1986:67). Under this policy, where missionary stations were built, 'Salems' were also established, which meant that converts were required to move out of their traditional homes and settle in the 'Christian quarters' or 'Salems' on the outskirts of the community (Kpobi 2008:76). In the Salems, these converts could be well-monitored to grow in their faith.

According to Kpobi (2008:76), the objectives of this policy were to:

- produce 'refined' Ghanaian Christians, whose conduct and lifestyle would become a beacon of light to their unconverted families and friends

- make pastoral care easier for the missionaries.

In view of the above, Christian converts were subjected to strict disciplinary action to ensure that there were no deviations from church regulations (Ekem 2009:85). In Ekem's (2009) commendation, he said:

The quality and profundity of Christian conversions often left much to be desired, because it was not unusual for some converts to slip back into the 'heathen customs' observed by their nonChristian contemporaries. (p. 84)

By 1855 other significant stations had been established at Abokobi, the Krobo area, Aburi, Kyebi, Abetifi, Nsaba, Anum and Ada (Kpobi 2008:76). It should be noted at this point that, even though the Missionaries had good reasons for what they did, it eventually resulted in the separation of the Christian converts from their kith and kin, thus, creating a cleavage in the community. It did serious harm to the Africans in that Africans lived a communal life. It also undermined the authority of traditional rulers and family elders.

\section{Economic development: Agriculture and trade}

Adei (2004:8) argues that the second dimension of nation building has to do with achieving economic progress, in the sense of improving the material welfare of the citizenry. According to Agbeti (1986:70), the Western Europeans deemed proper commerce as one of the best means of promoting civilisation and Christianity in Africa. In pursuance of this the Basel Mission engaged in agricultural, commercial and industrial activities (Smith 1966:55). The West Indians were engaged in the cultivation of plantations such as: orange and mango trees, local vegetables and bananas, yams, beans and groundnuts, as well as coffee, tobacco, cotton, sugar-cane and breadfruit trees (Debrunner 1967:129). The Basel Missionary agriculturists established a 'farm school' purposely to train 'Africans in scientific cultivation (Agbeti 1986:70). Reindorf (2007:272-273, 281), reports that the better classes amongst the converts, the educated community, refrained from agriculture.

Though originally, trade was not a policy of the Mission, it was precipitated by difficult circumstances that characterised the supply of some essential commodities for the missionaries and other Europeans working in the Gold Coast. One of the aims of the Basel Mission was that, legitimate trade in agricultural products should replace the slave trade (Agbeti 1986:70). This approach was therefore used to spearhead the abolition of slave trade and domestic slavery (Debrunner 1967:173). This policy therefore led to the formation of a Mission Trading Commission. It was later converted into the Basel Mission Trading Company in 1859 (Debrunner 1967:131-132). Union Trading Company later became the official title of the Mission's commercial enterprise (Agbeti 1986:69). The money acquired from these commercial enterprises helped the advancement of the Gospel and growth in missionary work. Part of the income was used to subsidise the building of schools, chapels, mission houses and for the training of artisans.

\section{Establishment of western education}

The 'bringing of civilisation' was a significant motive for European mission to Africa, and it became evident that education and Western civilisation were inseparable bedfellows. In that sense, education formed a strong backbone of the Basel Mission in Ghana. It was a primary objective of the missionaries to establish schools that would 'enable the congregations to read the Bible and to use the hymnbook' (Aboagye 2013:70). Furthermore, the established mission schools would provide an all-round education for indigenous African youths. Elias Schrenk of the Mission wrote to underscore the stated policy in 1867:

If we had a nation with formal education, able to read and to write, my plans for mission work would be different. But now I am convinced that the opening of schools is our main task. I have a low opinion of Christians who are not able to read their Bible. (Debrunner 1967:145)

To achieve the desired objective regarding education and training, two English schools were begun in 1843 in Christiansburg and Akropong. This was also followed by the establishment of Catechist Institutes at Akropong and Osu (Christiansburg), with the objective of training God-fearing young men from amongst the congregations as teachers and catechists (Debrunner 1967:145).

By 1853, the first batch of trained catechists - David Asante, William Yirenkyi, Jonathan Bekoe Palmer, and Paul Staudt Keteku - formed a nucleus of the indigenous collaboration force of the Basel Mission. Moreover, the school system of the Basel Mission produced many young men who were employed as government clerks. Training was also 
given in carpentry, masonry, agriculture and other crafts. A vocational school for the training of girls in needle work was also established, with the objective of training them to become good housewives and to serve God better. In a nutshell, a large number of people who became Christians were groomed in these schools (Agbeti 1986:67).

\section{Development of the vernacular into written materials}

The Basel Mission Society had a language policy which was an effective tool for missionary work. Their aim was to train the indigenous people to read the word of God in their own mother tongue. Their policy was that at all cost the African must hear the Gospel, read the Bible, worship and be taught in his or her own language. In view of this, the Basel Mission insisted on using the local language to evangelise. Every missionary was therefore trained in language skills and encouraged to learn language on arrival (Kpobi 2008:78). The Twi and Ga languages were selected for special study and became important parts of the curriculum of any school established by the Basel Mission (Kpobi 2008:78).

The major players in this aspect were Johannes Zimmermann and Rev. J.G. Christaller. Johannes Zimmermann produced the Ga Primer, Grammar and Dictionary in 1857. This was published in two volumes - 'A grammatical sketch of the Ga language' - in 1858. He also revised the New Testament in Ga in 1869. Rev. J.G. Christaller worked on the Twi language. Within six years, he was able to publish the four Gospels and the Acts of the Apostles in the Twi language. He also prepared other devotional materials in Twi for use in schools. He also produced the monumental Twi Dictionary in 1881. All these things were carried out in an effort to facilitate missionary work amongst the indigenes (Debrunner 1967:173). David Asante and Jonathan Bekoe Palmer were indigenes that helped Basel missionaries in achieving this policy (Debrunner 1967:143).

\section{Missiological implications of the developmental activities}

The Lausanne occasional paper 21 states that:

Only the gospel can change human hearts, and no influence makes people more human than the gospel does. Yet we cannot stop with verbal proclamation. In addition to worldwide evangelization, the people of God should become deeply involved in relief, aid, development and the quest for justice and peace. (Lausanne Movement 1982:n.p.)

A similar thought was shared in the Brussels Statement on Evangelization and Social Concern (1999:7). According to Bosch (1991:100), the firstwords the LukanJesus spokein public (Lk 4:18-19) contains a programmatic statement concerning his mission to reverse the destiny of the poor. The Third Lausanne Congress on World Evangelisation (2010:13-14) refers to this approach to mission as a 'godly fulfilment of the mandate to provide for human welfare'.
Missiologically, the Salem system introduced by the Basel Mission Society, can be seen in the light of the style of living in the early church (Ac 2:41-47). It also served as one of the best options for discipleship for that period. It is impossible to participate in evangelism and church planting without discipleship (eds. Walls \& Ross 2008:24-35). They both move together. Bosch (1991:56) refers to mission as the disciplemaking assignment of the church. It is therefore important that every local church must have a philosophy of ministry that emphasises the significance of discipleship and promotes a process for facilitating such maturity. The church must provide relational opportunities for congregants, matching those who need to grow with individuals and ministries that facilitate growth (Barna 2001:31; Malphurs 1996:33-34). The Salem communities established by the Basel Mission on the Gold Coast provided the opportunity for believers to be disciples. It also served as a way of ensuring that the new converts were steadfastly established in their new faith. Moreover, the Salem system enabled the indigenous believers to receive the needed training for effectiveness and efficiency in their later work.

Further developmental and missiological accomplishment of the Mission included the establishment of educational institutions for the promotion of evangelism, as well as the growth of the communal and national economy. Education offered the people great opportunities, and enhanced their awareness and/or political consciousness. Again, the role of women, who by tradition and custom were hitherto woefully demeaned, gained a better image through female education and training. Furthermore, The Basel Mission Society did very well by developing agriculture. The introduction of new crops and the establishment of plantations enabled the indigenous people to improve themselves in terms of food production (Agbeti 1986:70; Hildebrandt 1987:194). The Mission later put trained Ghanaians in charge of the institutions they had established. Thus, Ghanaians had jobs to do and experienced an improved standard of living. The mission of the church is not only to preach the gospel but also to be concerned regarding the welfare of the people within and outside the church (eds. Walls \& Ross 2008:35, 46-47).

The development of the vernacular languages into writing is another missiological issue to be noted. This approach enabled indigenous Christians to read and understand the Bible in their own language. Sanneh (2008:3) submits that, the eagerness of Protestants to translate the Bible demonstrated that the Bible is a crucial standard of authority. Throughout Africa, the Bible is held in high esteem because of its relevance to the realities in many African communities (Jenkins 2006:18, 23). Sanneh (1983:180) argues that the submission of the Bible to the regenerative capacity of African perception is what led to the renewal of Christianity through the independent and indigenous churches of Africa. The practice of vernacular language transcription and Bible translation characteristically makes the recipient cultures the true and final locus of the proclamation (Sanneh 2008:29). This implies that listening to the gospel, and reading the Bible in one's mother tongue, minimises the presumption of cultural rejection. 
Finally, the Basel Mission's spearheading of the abolition of domestic slavery was a positive step. It led to the affirmation and protection of human rights in the country (Debrunner 1967:173). According to the World Council of Churches (2013a:61-62), action towards healing and wholeness of the life of individuals and the transformation of structures that dispense injustice in communities are important expressions of mission. This approach to mission forms part of the diaconal approach to mission (Kritzinger, Meiring \& Saayman 1994:37). They constitute the fourth mark in the 'Five Marks of Mission' of the Anglican Consultative Council (eds. Walls \& Ross 2008:35, 46-47).

\section{Conclusion}

This article started with the background of why it is important that religious people should be concerned of national development. This was supported with God's command to the Jews in Babylon (Jr 29:4-7). It was argued that even though this command was sent to the Jews in exile, its content is still relevant to Christians and all missionary organisations. In view this; the history of the presence of the Basel Mission Society in Ghana was discussed followed by their mission policies and activities. The missiological implications of the policies and activities of the Basel Mission Society were also discussed. It was finally argued that as the commandment in Jeremiah 29:3, says, when it is well with the nation it shall be well with the Jews in Babylon, in a similar way, the developmental activities of the Basel Mission Society in Ghana, served as a bridge for evangelism. It also broke down prejudice and suspicion, and opened closed doors for the Gospel. The spreading of the Gospel gathered momentum and advanced in Akwapim, the Ga lands, Yilo Krobo, Prampram, Adafo, Akim, Akwamu and beyond. 'Salems' were established at Akropong, Abokobi, in the Krobo area, Aburi, Kyebi, Abetifi, Nsaba, Anum and Ada.

\section{Acknowledgements Competing interests}

The author declares that he has no financial or personal relationships which may have inappropriately influenced him in writing this article.

\section{References}

Aboagye, J.Y., 2013, 'An evaluation of the contribution of the Basel mission and Presbyterian church of Ghana to the socio-economic development of the Agogo traditional area', Unpublished MPhil Thesis, Kwame Nkrumah University of Science And Technology, Kumasi.

Adei, S., 2004, Leadership and national building, Combert Impressions, Accra.

Agbeti, K.J., 1986, West African church history, E.J. Brill, Leiden.

Balia, D. \& Kim, K. (eds.), 2010, Witnessing to Christ today, Edinburgh 2010, Volume II, Regnum Books International, Oxford.

Barna, G., 2001, Growing true disciples: New strategies for producing genuine followers of Christ, Waterbrook Press, Colorado Springs.

Bosch, D.J., 1991, Transforming mission: Paradigm shifts in theology of mission, Orbis, Maryknoll.

Brussels Statement on Evangelization and Social Concern, 1999, Transformation: An International Journal of Holistic Mission Studies 16(2), p. 7, Oxford Centre for Mission Studies, Oxford.
Buijs, J.G., 2004, 'Religion and development', in A.K. Giri, A. van Harskamp \& O. Salemink (eds.), The development of religion: The religion of development, p. 105, Eburon Uitgeverij, Delft.

Cordaid, ICCO \& the Institute of Social Studies, 2006, Religion: A source for human rights and development cooperation, BBO, The Hague.

Debrunner, H.W., 1967, A history of Christianity in Ghana, Waterville Publishing House, Accra.

Ekem, J.D.K., 2009, Priesthood in context, Son Life Press, Accra.

Ghana Statistical Service, 2012, Population \& housing census 2010, Sakofa Press Limited, Accra.

Grier, R., 1997, 'The effect of religion on economic development: A cross national study of 63 former colonies', KYKLOS 50(1), 47-50. http://dx.doi.org/10.1111/14676435.00003

Hendriks, J., 2010, 'A change of heart: Missional theology and social development', in L. Swart, H. Rocher, S. Green \& J. Erasmus (eds.), Religion and social development in post-apartheid South Africa: Perspective for critical engagement, p. 275, Sun Press, Stellenbosch.

Hiebert, P.E., 1989, 'Anthropological insight for whole ministries', in E.J. Elliston (ed.), Christian relief and development, p. 75, Word Publishing, Dallas.

Hildebrandt, J., 1987, History of the church in Africa, African Christian Press, Achimota. Iroegbe, P., 1996, The king of politics and communalism: Towards justice in Africa, International UP, Owerri.

Jenkins, P., 2006, The new faces of Christianity: Believing the Bible in the global South, Oxford University Press, Oxford.

Kpobi, D.N.A., 2008, Mission in Ghana: Ecumenical heritage, Asempa Publishers, Accra.

Kritzinger, J.J., Meiring, P.G.J. \& Saayman, W.A., 1994, On being witnesses, Orion Publishers, Johannesburg.

Kudadjie, J.N. \& Aboagye-Mensah, R.K., 1991, The Christian and national politics, Asempa Publishers, Accra.

Lausanne Movement, 1982, LOP 21, Evangelism and social responsibility: An evangelical commitment, viewed 12 October 2013, from http://www.lausanne. org/content/lop/lop-21

Malphurs, A., 1996, Strategy 2000: Churches making disciples for the next millennium, Kregel, Grand Rapids.

Marshall, K., 1999, Development and religion: A different lens on development debates, viewed 16 December 2014, from www.wfdd.org.uk/articlesandtalks. html\#marshall

Naude, C.F.B., 1991, 'The role of religion in the reconstruction of society', in W.S. Vorster (ed.), Building a new nation, pp. 83-85, University of Pretoria, Pretoria.

Odamten, S.K., 1978, The missionary factor in Ghana's development: 1820-1880, Waterville Publishing House, Accra.

Odumuyiwa, E.A., 2006, 'Christianity, governance and development: A case study of Nigeria in the 21st century', in R.A. Raji (ed.), Religion, governance and development in the 21st century, p. 211, Olabisi Onabanjo University, Ago-Iwoye.

Omenyo, C.N., 2006, Pentecost outside pentecostalism, Boekencentrum Publishing House, Netherlands.

Pierson, P.E., 1989, 'Mission and community development: A historical perspective', in E.J. Elliston (ed.), Christian relief and development, p. 7, Word Publishing, Dallas.

Presbyterian Church of Ghana, 2013a, History, viewed 13 June 2013, from http:// www.pcgonline.org/index.php/about-us/history-of-pcg

Presbyterian Church of Ghana, 2013b, History of Presbyterian Church of Ghana, viewed 13 June 2013, from http://anumpresby.com/pcg_history/pcg_history.htm

Reindorf, C.C., 2007, The history of the Gold Coast and Asante 1500-1800, 3rd edn., University of Ghana, Accra.

Sanneh, L., 1983, West African Christianity: The religious impact, Orbis Books, Maryknoll.

Sanneh, L., 2008, Translating the message: The missionary impact on culture, Orbis, Maryknoll.

Sarpong, P.K., 1990, 'What church, what priesthood for Africa?', Theological education in Africa: Quo vadimus?, World Council of Churches, Geneva.

Smith, N., 1966, Presbyterian Church of Ghana 1835-1960, A younger church in a changing society, Ghana University Press, Accra.

The Third Lausanne Congress on World Evangelization, 2010, Cape Town Commitment, Cape Town.

Walls, A. \& Ross, C. (eds.), 2008, Mission in the 21st century: Exploring the five marks of global mission, Darton, Longman and Todd Ltd., London.

Weber, M., 2002, The Protestant ethic and the spirit of capitalism, New introduction and translation by S. Kalberg, Blackwell, Oxford.

Wilson, S., 1989, 'Defining development in social terms', in E.J. Elliston (ed.), Christian relief and development, pp.145-158, Word Publishing, Dallas.

World Council of Churches, 2013a, 'The Church: Towards a common vision', in M. Lorke \& D. Werner (eds.), Ecumenical vision for 21st Century, pp. 61-62, WCC Publications, Geneva.

World Council of Churches, 2013b, 'Together towards life', in M. Lorke \& D. Werner (eds.), Ecumenical vision for 21st century, p. 68, WCC Publications, Geneva. 